\title{
Autonomous trucks: A supply chain adoption perspective
}

\begin{abstract}
Autonomous trucks can potentially have a huge impact on supply chain networks. Though gaining a lot of attention in the industry, the topic has gained sparse interest from academia. This paper sets out to answer the question: What factors could potentially predict autonomous truck adoption? Though it is inherently difficult to make predictions for the future, we have conducted scenario analysis based on input from key experts in the field. Our findings suggest that technological maturity and regulation will be the two most important factors to observe, while also being very uncertain.
\end{abstract}

\section{Introduction}

As trucking manufactures continue to run pilots with autonomous trucks, experts agree that self-driving trucks is the future of supply chain road transportation $[1,2]$. Legislators in many truck-manufacturing countries are very supportive and the Swedish infrastructure minister says he views Sweden as a major future arena for autonomous vehicles [3].

Though many challenges for autonomous trucks remain to be solved, long-distance terminal to terminal transportation seem to be where companies like Einride [4] are focusing their efforts. In the U.S., Uber's OTTO used its autonomous trucks to provide beer delivery services to Budweiser since 2016. However, Uber announced its decision in 2018 to stop developing autonomous trucks and to focus its autonomous vehicle technology solely on cars.

Several current trends, such as the driver shortage [5], digitalization and vehicle electrification are creating synergies for a shift in the long-term outlook on supply chain transportation. Furthermore, projects on Platooning are cancelled [for example, 6] and some believe this to be not only due to the lack of profitability, but also because the truck manufacturers want to focus on autonomous driving.

Although autonomous trucks could have huge potential impacts, Supply Chain Management (SCM) research has not sufficiently addressed this field. Most people are still unaware of how self-driving trucks will reshape most supply chain networks. Prockl and Sternberg [7] state: "Depending on the country, time represents the largest or second-largest cost for motor carriers, with the salary cost of the drivers accounting for 20-55 percent of the operator's total costs” (p. 276). With fully self-driving trucks, the driver cost can be decreased or eliminated. Combined with potentially much lower operating cost of an electrified truck, the cost of road freight transportation costs can be potentially reduced by $50-80 \%$. As most supply chain optimization is done based on service levels, holding costs and transportation costs [8,9], significantly reducing one factor (transport cost) will can have massive effects on the optimal configuration of supply chain networks.

Given those changes, another potential effect is the change in the ecosystem of actors in the supply chain. Manufacturers of autonomous trucks might not become suppliers to carriers, but rather servitize the transport function and sell directly to shippers or logistics service providers. Logistics is highly outsourced [10] and many motor carriers are owner-operators or have small fleets [11].

Obviously there will be significant implications to supply chains and it is strategically important for researchers and practitioners to understand this emerging topic. Hence this paper sets out to explore potential adoption of autonomous trucks from a supply chain transport perspective.

Our approach is scenario analysis based on expert interviews. Our research context is Sweden, which though it is a limited market, has several manufacturers (e.g., Volvo Trucks, Scania and Einride), long distances and high driver wages (both driving up transport cost) as well as a relatively agile legislation process. All these factors make Sweden a market for early autonomous truck adoption and a viable context for the current study.

Recently SCM research have highlighted the importance of studying the intersection of public policy and government regulation (PPGR) and SCM [12]. We aim at making a first modest contribution to the area of autonomous trucks in the intersection of PPGR and SCM.

Using ARA, PESTEL analysis and technology adoption, this paper sets the ground for future research on autonomous trucks and their role in supply chain management.

This paper is structured as follows. In the next section, we offer a brief overview of the terminology and technologies related to autonomous trucks. After discussing the theoretical framework in the following section, we present the details of data and methodology. Results and conclusion are provided in the end. 
Please note that we do not address safety concerns [13] or legal barriers in-depth [1, 2], but rather depart from the current state of affairs and the knowledge of our expert panel.

\section{State of the art: Self-driving}

This section addresses the level of self-driving as well as the current implementation status (latest pilot projects). This is by no means intended to be an exhaustive coverage of the field, but rather to introduce the terminology and concepts related to autonomous trucks, which is critical to conduct the current study.

Dynamic Driving Task (DDT) refers to the trip carried out without some (or entirely) human involvement. Operational Design Domain (ODD) refers to the area where the transport actually (or is intended to) takes place.

\subsection{Levels of self-driving}

SAE International has produced a description of the levels of autonomy of vehicles [14]. The scale lists 6 levels, from zero (no automation) to five (fully autonomous DDT in the ODD).

- Level 1: Driver assistance. The DDT is on a level where the vehicle uses information about driving conditions to, for example, steer, accelerate, break or perform cruise control.

- Level 2: Partial automation, a level where the vehicle can perform several Level 1 functions simultaneously.

- Level 3: Conditioned automation. The vehicle can perform all aspects of DDT, but the vehicle needs monitoring of a human driver who can intervene on the request of the vehicle.

- Level 4: Highly automated. The level where the vehicle can adapt and perform tasks it would otherwise request a human to do. At this level, the vehicle does not actually need monitoring, but still has it.

- Level 5: Full automation, i.e., the vehicle operates just as good (or better) as a human driver in all possible situations in the ODD.

Though these levels, as pointed out by a reviewer, are not very granular, these are the ones commonly used in the academic and grey literature [13].

\subsection{Existing pilots}

All Western truck manufacturers are currently involved in pilot projects on autonomous driving.
The autonomous truck startup TruSimple has recently signed a contract with the United States Postal Service to run its self-driving trucks for mail delivery in a two-week pilot program in Arizona and Texas [15]. Although the testing truck is fully autonomous, there will be a safety engineer and driver on board to monitor vehicle performance and ensure public safety. In addition, Daimler has been testing autonomous trucks in Nevada over the past years and Einride are now testing entire driverless autonomous trucks (so called "T-Pods) in Sweden [4].

\section{Theoretical frame}

\subsection{Industrial Network Approach (INA)}

To understand industry setups scholars have frequently used the INA model ${ }^{1}$. It is a basic rationale of the network model that the individual firm is dependent on resources controlled by other companies (Skjøett-Larsen 2000). However, new technologies often has an effect on the actor constellation, creating intermediaries and disrupting through disintermediation [16].

There is an inherent tendency in the development of industrial networks that the links become stronger and more stable over time. When applying the industrial network approach to analyze control structures in supply chains, the focus is mainly on three components [17]:

- Actors, i.e. the people and institutions within the network.

- Resources, i.e. the material and immaterial resources owned by the actors.

- Activities, i.e. the actions executed by actors based on specific resources.

The central features of the network's activity layer are interdependences and adjustments [18]. Interdependences are central because activities never work in isolation, which in particular is true for road freight transportation. In road freight transportation, several different actors are involved, though most SCM literature traditionally has focused on shippers, logistics service providers and carriers [19].

\subsection{PESTEL}

All supply chains are operating in a business environment, where political and economical macro factors set the rules of competition, offer challenges, opportunities and risks [20].

An often applied tool to understand the factors surrounding a firm, is PESTEL analysis [21, 22]. The PESTAL analysis means investigating an environment based on these categories:

\footnotetext{
${ }^{1}$ Sometimes referred to as the Actors Resources Activities (ARA) model.
} 
- Political

- Economic

- Sociocultural

- Technological

- Environmental

- Legal

For a thorough definition and explanation of all the factors, we refer to Johnson, Whittington [23]. It is apparent that PESTEL analysis presents a rather comprehensive tool for the current study of autonomous trucks.

\subsection{Technology acceptance model}

To study innovation adoption in supply chains, SCM scholars typically draw from management information systems (MIS) theories [24, 25] which have a long history of studying adoption of technical innovations $[26,27]$.

Rogers [26] introduced the technology acceptance model (TAM), suggesting that the perceived ease of use (PEU) and perceived usefulness (PUE) determine an individual's intention to use a technology (particularly information systems) [21]. Although later developments of TAM have introduced more nuanced frameworks [e.g., 28], for the sake of simplicity we stick with the classic TAM.

\section{Data and methodology}

Given the conceptual nature of this investigation and the fact that autonomous trucks are not yet operating outside test scenarios (i.e., not in production and real operations), we apply an inductive method, using scenario analysis based on expert interviews to elaborate different possibilities.

As mentioned in the previous section, the delimitation is Sweden, due to both the suitability of Sweden and the time constraints the project faced.

\subsection{Data collection}

The interviewees consulted for the purpose of the study are listed in Table $\mathbf{1 .}$

Table 1. The interviewees

\begin{tabular}{|l|l|c|}
\hline Interviewee & Perspective & Interview round\# \\
\hline $\begin{array}{l}\text { CEO, truck } \\
\text { manufacturer 1 }\end{array}$ & $\begin{array}{l}\text { Autonomous } \\
\text { trucks pioneer }\end{array}$ & 1 \\
\hline $\begin{array}{l}\text { Business area } \\
\text { manager, LSP 1 }\end{array}$ & LSP & 1 \\
\hline $\begin{array}{l}\text { Senior manager } \\
\text { truck manufacturer } \\
2\end{array}$ & $\begin{array}{l}\text { Truck } \\
\text { manufacturer }\end{array}$ \\
\hline
\end{tabular}

\begin{tabular}{|c|c|c|}
\hline $\begin{array}{l}\text { Sales manager, } \\
\text { truck manufacturer } \\
1\end{array}$ & $\begin{array}{l}\text { Truck } \\
\text { manufacturer }\end{array}$ & 1 \\
\hline Truck driver & Truck operations & 1 \\
\hline $\begin{array}{l}\text { Purchasing } \\
\text { manager, Work } \\
\text { apparel company }\end{array}$ & Purchaser & 1 \\
\hline $\begin{array}{l}\text { SCM researcher, } \\
\text { focused } \\
\text { transportation }\end{array}$ & Research & 1,2 \\
\hline $\begin{array}{l}\text { Negotiator, } \\
\text { Swedish transport } \\
\text { union }\end{array}$ & Transport union & 2 \\
\hline $\begin{array}{l}\text { SCM researcher 2, } \\
\text { focused } \\
\text { digitization }\end{array}$ & Research & 2 \\
\hline $\begin{array}{lr}\text { Director } & \text { public } \\
\text { affairs, } & \text { Truck } \\
\text { manufacturer } 3\end{array}$ & $\begin{array}{l}\text { Truck } \\
\text { manufacturer }\end{array}$ & 2 \\
\hline $\begin{array}{l}\text { Transport } \\
\text { Manager, LSP } 2\end{array}$ & LSP & 2 \\
\hline $\begin{array}{l}\text { CEO, National } \\
\text { road association }\end{array}$ & $\begin{array}{l}\text { Industry } \\
\text { association }\end{array}$ & 2 \\
\hline
\end{tabular}

\subsection{Scenario analysis}

Scenario analysis is a useful method when approaching an area of high uncertainty [23]. As there are an infinite number of possible scenarios for adoption of autonomous trucks, the scenario analysis helps to narrow down to a few plausible scenarios, based on the Key Drivers of Change (KDC). KDCs are those factors that in a macro environment are likely to have a significant effect on the success or failure. It is important to note, that KDCs will differ between different industries and there could be significant interaction effects between different KDCs [23].

We used a two-step approach. In round 1, the scenarios were created. In round 2, the interviewees gave their input on the scenarios from round 1 .

\section{Results}

This section elaborates on the empirical data analysis and results.

\subsection{Weighing of factors}

Presented with a translated PESTEL framework, the interviewees were asked to identify trends, their potential impact (1-10) and the uncertainty (1-10) of the impact of that trend.

The trends identified by the participants are listed in Table 2. Only trends that were mentioned twice or more were included in the listing. 
Table 2. Summary of the PESTEL analysis (based on interview round \#1, see Table 1)

\begin{tabular}{|l|c|c|c|}
\hline Trend & $\#$ & $\begin{array}{l}\text { Average } \\
\text { effect }\end{array}$ & $\begin{array}{l}\text { Average } \\
\text { uncertainty }\end{array}$ \\
\hline $\begin{array}{l}\text { Autonomous } \\
\text { driving } \\
\text { technology }\end{array}$ & 7 & 7.5 & 4.7 \\
\hline $\begin{array}{l}\text { Customer } \\
\text { climate } \\
\text { demands }\end{array}$ & 6 & 5.8 & 2. \\
\hline Electrification & 5 & 6.2 & 4.4 \\
\hline Connectivity & 5 & 6.4 & 2.0 \\
\hline $\begin{array}{l}\text { Increased driver } \\
\text { shortage }\end{array}$ & 5 & 6.8 & 2.4 \\
\hline $\begin{array}{l}\text { Deregulation of } \\
\text { cabotage }\end{array}$ & 4 & 6.0 & 5.0 \\
\hline $\begin{array}{l}\text { Deregulation of } \\
\text { autonomous } \\
\text { vehicles }\end{array}$ & 3 & 9.0 & 5.0 \\
\hline $\begin{array}{l}\text { Increased cost } \\
\text { pressure }\end{array}$ & 3 & 6.3 & 3.0 \\
\hline $\begin{array}{l}\text { Increased } \\
\text { transport } \\
\text { demand }\end{array}$ & 3 & 6.3 & 2.7 \\
\hline $\begin{array}{l}\text { Increased safety } \\
\text { demands }\end{array}$ & 3 & 6.3 & 1.7 \\
\hline $\begin{array}{l}\text { Increased } \\
\text { policy climate } \\
\text { demands }\end{array}$ & 2 & 8.5 & 1.5 \\
\hline
\end{tabular}

How far research and testing of autonomous driving (without reference to a specific SAE level) gets was, not surprisingly, a major factor believed to determine adoption. The second largest factor was believed to be customer climate demands, implying that autonomous trucks are electrified and more environmentally friendly. Electrification was also identified by 5 interviewees, so were connectivity and increased driver shortage. The driver shortage was viewed by the experts as a strong factor (6.8) with relatively low uncertainty (2.4).

Four interviewees considered the European cabotage regulation [29] as a major factor determining truck adoption in Sweden. As mentioned in the motivation for choosing Sweden as a case, Sweden has high driver wages and the cabotage regulation limits access of foreign (low-cost) drivers. The interviewees reasoned that limited access to low cost transportation would make autonomous trucks more attractive and vice versa.

Further regulations were also mentioned by several interviewees. Three interviewees mentioned autonomous driving deregulation as a major factor affecting adoption. In particular the truck manufacturers in the interview group did not view regulations as an obstacle. Another potential regulation, increased policy demands on climate, was mentioned by two interviewees.

\subsection{Scenario elaboration}

According to the scenario analysis approach, transitory or "in-between" states should be avoided; otherwise, the beholder will overly focus on that. Given the input from the expert interviews, we followed the suggestions by Johnson, Whittington [23] and created a 2x2 matrix (Figure 1).

\begin{tabular}{|c|c|c|}
\hline \multirow[b]{2}{*}{$\begin{array}{l}\text { SAE Level } 4 \text { is a } \\
\text { reality and } \\
\text { widespread in } \\
\text { applicable ODDs }\end{array}$} & Tech-Disruption & Complete \\
\hline & $\begin{array}{l}\text { Autonomous technique } \\
\text { becomes the de-facto } \\
\text { standard for non-city } \\
\text { transports and reaches SAE } \\
\text { Level } 5\end{array}$ & $\begin{array}{l}\text { Competition } \\
\text { An open Europe with and all } \\
\text { actors have access to the } \\
\text { same technology as in the } \\
\text { Tech-Disruption scenario, but } \\
\text { also with large-scale access } \\
\text { to low cost drivers }\end{array}$ \\
\hline \multirow{3}{*}{$\begin{array}{l}\text { Slow technology } \\
\text { development } \\
\text { and/or legal } \\
\text { barriers }\end{array}$} & Status Quo & Open Border \\
\hline & $\begin{array}{l}\text { Business-as-usual with minor } \\
\text { changes in the dimensional } \\
\text { factors (technology \& } \\
\text { deregulation). Autonomous } \\
\text { driving requires surveillance } \\
\text { and has limited use. }\end{array}$ & $\begin{array}{l}\text { Fiercer competition from } \\
\text { low-cost carriers following } \\
\text { cabotage deregulation. } \\
\text { Autonomous driving } \\
\text { requires surveillance and } \\
\text { has limited use. }\end{array}$ \\
\hline & $\begin{array}{l}\text { Cabotage rules } \\
\text { remains similar to } \\
\text { current rules }\end{array}$ & $\begin{array}{l}\text { European cabotage } \\
\text { gets entirely } \\
\text { deregulated }\end{array}$ \\
\hline
\end{tabular}

Figure 1. The four major scenarios identified

Four major scenarios are outlined. As the maturity of the autonomous driving technology is central to adoption, it represents the $\mathrm{Y}$-axis. This can also be referred to as the Perceived Easy of Use [30]. On the Xaxis we selected Cabotage rules.

In line with Fagnant and Kockelman [1], current rules that prohibit large-scale adoption of autonomous trucks, might prevail for a long time. The implication is then obviously Status Quo.

Access to cheap labor lowers transportation costs and can serve as a barrier to increasing efficiency by entrenching the model of low cost transportation. This has been extensively covered by Sternberg et al. [31], showing that deregulation of domestic transportation opens up for low-cost labor from countries outside Europe.

High transportation costs are a major driver for supply chain actors to invest in autonomous trucks - if the technology is available. In effect, the higher the transport costs, the higher the Perceived Usefulness (PUE) of autonomous trucks from the perspective of act, paving the way for the scenario of "Tech-Disruption".

Finally, the scenario "Complete competition" outlines an open Europe with access to both automation and low-cost drivers. Such a scenario is highly difficult to predict.

\subsection{Disruption}

It is inherently difficult to predict disruption, however several experts in the panel point out a future 
where the carriers are not the primary customers of selfdriving trucks.

From the INA perspective, the ownership of the resources (the trucks) have been continuously shifting to the truck manufacturers, as the motor carriers increasingly are leasing rather than buying their trucks from the manufacturer.

Experts indicate that the logistics service providers might purchase transportation directly from the truck manufacturer rather than from the motor carrier, thereby disrupting the motor carrier industry.

\section{Concluding Discussion}

This paper represents a first modest contribution towards understanding autonomous truck adoption in the light of factors that influence the perceived usefulness of truck automation.

Based on interviews with leading experts on autonomous trucks, we have identified the main factors affecting its adoption and delineated four major future scenarios. Given the insights our interviewees have, it is clear that the industry is facing a lot of uncertainty, not only in terms of technical development but also in terms of economic and technical regulations. It should again be noted, that the most likely scenario is something in between the given scenarios.

The different scenarios are likely to influence the industry structure. As owner-operators are unlikely to become the owners of autonomous trucks, the landscape will inevitably change - unless we stay in Status Quo. Given the current structure of the industry and the shift in resource control, we suggest using ARA to further investigate how these scenarios will re-shape supply chains.

Sweden, though being a major truck manufacturing nation, is a small market. Hence, we suggest future research in other markets, such as United States, China or continental Europe.

\section{Acknowledgements}

The authors would like to express our gratitude to Carl Mikael Widman and Erik Enfors for sharing their empirical work with the authors.

\section{References}

1. Fagnant, D.J. and K. Kockelman, Preparing a nation for autonomous vehicles: opportunities, barriers and policy recommendations.
Transportation Research Part A: Policy and Practice, 2015. 77: p. 167-181.

2. Haboucha, C.J., R. Ishaq, and Y. Shiftan, User preferences regarding autonomous vehicles. Transportation Research Part C: Emerging Technologies, 2017. 78: p. 37-49.

3. EFN. 2018 [cited 2019 June 10th]; Available from: https://www.efn.se/tagg/tomaseneroth/sjalvkorande-lastbilar-snart-drift/.

4. Kane, M. Autonomous Einride T-pod Enters Service On A Public Road. 2019 [cited 2019 June 14th]; Available from: https://insideevs.com/news/350293/autonomo us-einride-t-pod-public-road/.

5. Prockl, G., et al., Antecedents of Truck Drivers' Job Satisfaction and Retention Proneness. Journal of Business Logistics, 2017. 38(3): p. 184-196.

6. Shiers, W. Daimler to pull plug on truck platooning. 2019 [cited 2019 June 15th]; Available from: https://www.commercialmotor.com/news/pro duct/daimler-pull-plug-truck-platooning.

7. Prockl, G. and H. Sternberg, Counting the Minutes : Measuring Truck Driver Time Efficiency. Transportation Journal, 2015. 54(2): p. 275-287.

8. Simchi-Levi, D., P. Kaminsky, and E. SimchiLevi, Designing and Managing the Supply Chain: Concepts, Strategies and Case Studies. 3rd edition ed. 2007, New York: McGraw-Hill.

9. Olhager, J., S. Pashei, and H. Sternberg, Design of global production and distribution networks: A literature review and research agenda. International Journal of Physical Distribution \& Logistics Management, 2015. 45(2): p. 138 - 158.

10. Deepen, J.M., et al., Beyond Expectations: an Examination of Logistics Outsourcing Goal Achievement and Goal Exceedance. Journal of Business Logistics, 2008. 29(2): p. 75-105.

11. Sternberg, H., T. Germann, and T. KlaasWissing, Who controls the fleet? Initial insights into road freight transport planning and control from an industrial network perspective. International Journal of Logistics: Research and Applications, 2013. 16(6): p. 493-505.

12. Pagell, M., B. Fugate, and B. Flynn, Call for Papers for the 2019 Emerging Discourse Incubator: Research at the Intersection of Supply Chain Management and Public Policy and Government Regulation. Journal of Supply Chain Management, 2018. 54(4): p. 89-92. 
13. Robert, L.P., Are automated vehicles safer than manually driven cars? AI \& Society, 2019. 34(3): p. 687-688.

14. SAE International, Taxonomy and Definitions for Terms Related to Driving Automation Systems for On-Road Motor Vehicles. 2016: Brussels, Belgium.

15. Boudway, I. and Bloomberg. USPS Is Testing Self-Driving Trucks to Move Mail and Packages Between Cities. 2019 [cited 2019 June 14th]; Available from: http://www.fortune.com/2019/05/21/uspstests-self-driving-trucks-autonomous-vehiclemail-delivery/.

16. Nagy, D., J. Schuessler, and A. Dubinsky, Defining and identifying disruptive innovations. Industrial Marketing Management, 2016. 57: p. 119-126.

17. Dubois, A. and L.-E. Gadde, The construction industry as a loosely coupled system: Implications for productivity and innovation. Construction Management and Economics, 2002. 20(7): p. 621-631.

18. Håkansson, H., et al., Business in Networks. 2009, Chichester, UK: John Wiley and Sons.

19. Stefansson, G., Collaborative logistics management and the role of third-party service providers International Journal of Physical Distribution \& Logistics Management 2006. 36(2): p. 76-92.

20. Sanchez-Rodrigues, V., et al., Establishing a transport operation focused uncertainty model for the supply chain. International Journal of Physical Distribution \& Logistics Management, 2008. 38(5): p. 388-411.

21. Kaplan, R.S. and D.P. Norton, Mastering the Management System. Harvard Business Review, 2008. January: p. 1-17.

22. Kaufmann, L., C. Thiel, and A. Becker, Supply Chain Management in the Mexican Pharmaceutical Industry, in Annual North American Research/Teaching Symposium on Purchasing and Supply Chain Management. 2005.

23. Johnson, G., et al., Fundamentals of Strategy. 4th edition ed. 2017, New Jersey: Pearson.

24. Hazen, B.T., R.E. Overstreet, and C.G. Cegielski, Supply chain innovation diffusion: going beyond adoption. International Journal of Logistics Management, 2012. 23(1): p. 119134.

25. Autry, C.W., et al., The effects of technological turbulence and breadth on supply chain technology acceptance and adoption. Journal of Operations Management, 2010. 28(6): p. 522-536.

26. Rogers, E.M., Diffusion of innovations. 1962, New York, NY: Free Press.

27. Grover, V., An Empirically Derived Model for the Adoption of Customer-based Interorganizational Systems. Decision Sciences, 1993. 24(3): p. 603-640.

28. Venkatesh, V., et al., User Acceptance of Information Technology: Toward a Unified View. MIS Quarterly, 2003. 27(3): p. 425-478.

29. Regulation (EC) No 1072/2009 of the European Parliament and of the Council of 21 October 2009 on common rules for access to the international road haulage market, in $L$ 300/72. 2009, http://eurlex.europa.eu/LexUriServ/LexUriServ.do?uri =OJ:L:2009:300:0072:0087:EN:PDF:

European Union. p. 72-87.

30. Rogers, E.M., Diffusion of innovations. 5th edition ed. 2003, New York, NY: Free Press.

31. Sternberg, H., et al., Cabotagestudien: A study on trucking deregulation in Scandinavia and beyond. 2015, Lund University: Lund, Sweden. 